\title{
EFEKTIVITAS PEMBELAJARAN MULTILITERASI TERHADAP KEMAMPUAN BERPIKIR KRITIS SISWA SEKOLAH DASAR PADA MATERI EKOSISTEM
}

\author{
Febrina Dafit, Dea Mustika, Siti Quratul Ain \\ Universitas Islam Riau \\ Email: febrinadafit@edu.uir.ac.id
}

Naskah diterima : 15 September 2018, direvisi : 20 September 2018, disetujui : 15 Oktober 2018

\begin{abstract}
The purpose of the study was to examine the effectiveness of multiliteracy learning towards elementary students' critical thingking skills in ecosystem material. Preliminary observations and discussion with the tracher were done to find out whether multiliteracy learning had already been implemented or not before. The learning design that was applied by the teacher was multiliteracy learning. Further, observation, interviews, and observation sheets were used to obtain the data related to teacher's and students' activity during the implementiom of multiliteracy learning. Then, test was employed to measure the level of students' critical thinking skills. After analyzing the data obtained, it can be concluded that there was a significant effect of multiliteracy learning towards elementry students' critical thingking skills. It coyld be proven from the average of score of experimental class was 17 whereas control class was 14.71. Students and teacher positively responded the implementation of multiliteracy learning. In other words, it can help in improving students' critical thinking skils and facilitate the learning process.
\end{abstract}

Keywords: Learning multiliteracy, Critical Thingking, Elementary students'

Pengutipan: Febrina Dafit, Dea Mustika, Siti Quratul Ain. (2018). Efektivitas Pembelajaran Multiliterasi terhadap Kemampuan Berpikir Kritis Siswa Sekolah Dasar pada Materi Ekosistem. JMIE: Journal of Madrasah Ibtidaiyah Education, 2(2), 2018, 181-193. jmie.v2i2.71.

Permalink/DOI: http://dx.doi.org/ 10.32934/jmie.v2i2.71 


\section{PENDAHULUAN}

Proses pembelajaran merupakan kegiatan utama dalam lingkungan pendidikan, karena dengan adanya proses pembelajaran maka dapat diartikan terjadinya interaksi dan pemanfaatan berbagai sumber daya yang ada baik dari potensi yang bersumber dari dalam diri maupun potensi yang ada di luar diri untuk mencapai tujuan belajar tertentu. Salah satu mata pelajaran yang menuntut adanya interaksi nyata dan pemanfaatan potensi adalah Ilmu Pengetahuan Alam (IPA). IPA adalah bagian pengetahuan manusia yang diperoleh dengan cara terkontrol, sedangkan pembelajaran IPA merupakan program untuk menambah dan mengembangkan pengetahuan, keterampilan dan sikap ilmiah dalam diri siswa. Poin-poin eksak dalam pembelajaran IPA dapat merangsang kemampuan berpikir kritis dan kreatif sehingga sangat baik untuk perkembangan siswa (Gibasa Learning Society, 2012).

Berpikir kritis adalah berpikir secara beralasan dan reflektif dengan menekankan pembuatan keputusan tentang apa yang harus dipercayai atau dilakukan. Kemampuan berpikir kritis dalam pembelajaran IPA biasanya diawali dengan rasa ingin tahu, sehingga penting bagi guru untuk merancang pembelajaran yang memberi kesempatan pada siswa untuk bereksplorasi, memberikan berbagai kemungkinan dan mencari sendiri jawaban yang lebih benar. Maslichah (2006) menyatakan peran guru dalam pembelajaran IPA hanyalah sebagai fasilitator, guru menyediakan sarana agar siswa dapat mengamati dan memahami obyek. Dengan demikian siswa dapat menemukan dan membangun konsep dalam struktur kognitifnya.

Namun saat ini, kemampuan berpikir kritis siswa dalam pembelajaran IPA khususnya di tingkat Sekolah Dasar belum sesuai dengan yang diharapkan. Guru yang monoton mengajar dengan cara konvensional dan mengabaikan proses-proses penting dalam pembelajaran IPA seperti mengamati dan memahami, akan membuat siswa hanya terfokus belajar pada hafalan teori dan konsep saja. Hal seperti ini tentunya akan berdampak pada rendahnya kemampuan berpikir siswa, karena dasar-dasar berpikir yang tidak dikuasai dengan baik dan dapat terus berlanjut hingga tingkat pendidikan berikutnya (Fauziah, 2010).

Diperlukan suatu inovasi yang dapat mengubah konsep belajar IPA konvensional pada konsep belajar IPA yang menarik dan menyenangkan. Usaha yang dapat ditempuh adalah dengan mengembangkan pembelajaran multiliterasi. Konsep keterampilan yang harus dikuasai dalam pembelajaran multiliterasi adalah kemampuan membaca pemahaman yang tinggi, kemampuan menulis yang baik, keterampilan berbicara dan keterampilan menguasai berbagai media digital (Morocco, 2008). Keempat keterampilan 
tersebut berkaitan dengan penguasaan literasi dan integrasi bahasa dengan ilmu lain untuk memperoleh suatu pengetahuan. Dengan pembelajaran multiliterasi pada IPA, maka siswa dapat memanfaatkan keterampilan berbahasa dan menulis dalam pembelajaran sehingga memunculkan kompetensi berpikir kritis, pemahaman konseptual, komunikatif serta mampu menghasilkan produk yang bermanfaat.

Berdasarkan latar belakang masalah yang telah dipaparkan, secara umum permasalahan dalam penelitian ini adalah bagaimanakah efektivitas pembelajaran multiliterasi terhadap kemampuan berpikir kritis siswa Sekolah Dasar pada materi ekosistem? Maka tujuan penelitian ini adalah untuk menelaah dan mendeskripsikan efektivitas pembelajaran multiliterasi terhadap kemampuan berpikir kritis siswa Sekolah Dasar pada materi ekosistem.

\section{METODE PENELITIAN}

Penelitian ini merupakan penelitian kuantitatif dengan metode quasi experiment serta menggunakan statisik deskriptif dengan membandingkan angka-angka statistik perbandingan antara variabel kontrol dan variabel eksperiman (Sukmadinata, 2013). Selanjutnya angka-angka tersebut dianalisis dan dideskripsikan menggunakan kata-kata. Desain penelitian yang dilakukan dalam penelitian ini adalah kuasi eksperimen nonequivalent groups pretest-postest (Schumacher, 2001).

Prosedur yang ditempuh dalam penelitian adalah tahap persiapan, pelaksanaan dan diakhiri dengan analisis hasil serta penyusunan laporan penelitian. Sampel penelitian adalah siswa kelas VI SDN 81 Kota Pekanbaru. Pengambilan sampel dilakukan dengan purposive sampling dengan tujuan penelitian ini dapat dilaksanakan secara efektif dan efisien terutama dalam hal pengawasan, kondisi subjek penelitian, waktu penelitian, kondisi tempat penelitian serta prosedur perizinan penelitian. Maka peneliti memilih sampel berdasarkan kebutuhan penelitian dan menganggap sampel tersebut bersifat representif.

Hipotesis penelitian ini adalah "Kemampuan berpikir kritis siswa kelas eskperimen yang belajar melalui pembelajaran multiliterasi lebih efektif daripada siswa kelas kontrol yang belajar melalui pembelajaran langsung." Hipotesis kuantitatif yang diuji pada penelitian ini adalah sebagai berikut:

1. $\mathrm{H}_{\mathrm{o} 1}$ : Tidak terdapat perbedaan berpikir kritis siswa kelas eskperimen yang belajar melalui pembelajaran multiliterasi lebih efektif daripada siswa kelas kontrol yang belajar melalui pembelajaran langsung. 
2. $\mathrm{H}_{\mathrm{a} 1}$ : Kemampuan berpikir kritis siswa kelas eskperimen yang belajar melalui pembelajaran multiliterasi lebih efektif daripada siswa kelas kontrol yang belajar melalui pembelajaran langsung.

Teknik pengolahan data dilakukan dengan dua cara yaitu analisis data atau metode deskriptif dan metode statistik. Metode deskriptif digunakan untuk mendeskripsikan data hasil penelitian. Metode statistik digunakan untuk keperluan pengolahan data kuantitatif seperti uji persyaratan data dan uji hipotesis. Setelah hasil statistik didapat selanjutnya dilakukan penarikan kesimpulan untuk untuk ditafsirkan maknanya. Data-data yang telah dikumpulkan kemudian dianalisis dengan menggunakan program sofeware SPSS.

\section{HASIL DAN PEMBAHASAN}

Data kemampuan berpikir kritis siswa diperoleh dari hasil pretest dan posttest siswa kelas eksperimen dan siswa kelas kontrol, data tersebut dapat dilihat pada tabel di bawah ini.

Tabel 1. Statistik Deskriptif Kemampuan Berpikir Kritis

\begin{tabular}{lcccccc|cccccc}
\hline \multirow{2}{*}{ Nilai } & \multicolumn{7}{c|}{ Eksperimen } & \multicolumn{7}{c}{ Kontrol } \\
\cline { 2 - 13 } & $\mathbf{N}$ & $\mathbf{X}_{\min }$ & $\mathbf{X}_{\max }$ & $\overline{\boldsymbol{x}}$ & $\mathbf{S d}$ & $\mathbf{\%}$ & $\mathbf{N}$ & $\mathbf{X}_{\min }$ & $\mathbf{X}_{\max }$ & $\overline{\boldsymbol{x}}$ & $\mathbf{S d}$ & $\mathbf{\%}$ \\
\hline Pretest & 25 & 4 & 17 & 11,00 & 3,9 & 36,67 & 24 & 4 & 21 & 11,29 & 3,67 & 37,63 \\
Postest & 25 & 8 & 26 & 17,00 & 3,83 & 56,67 & 24 & 9 & 21 & 14,71 & 2,84 & 49,03 \\
\hline
\end{tabular}

Skor Maksimal Ideal $=30$

Berdasarkan tabel di atas terlihat rataan skor pretest kemampuan berpikir kritis kelas eksperimen yaitu 11,00 dan kelompok kelas kontrol adalah 11,29. Dari hasil rataan pretest kemampuan berpikir kritis tersebut terlihat kemampuan awal berpikir kritis siswa kelas eksperimen dan kelas kontrol tidak jauh berbeda, artinya kemampuan berpikir kritis siswa kelas eksperimen dan kelas kontrol hampir sama sebelum dilakukan proses pembelajaran dengan pembelajaran multiliterasi bagi kelas eksperimen dan pembelajaran dengan metode ceramah bagi kelas kontrol. Begitu juga dengan standar deviasi skor pretest kemampuan berpikir kritis kelas eksperimen dan kelas kontrol yang tidak menunjukkan perbedaan yang cukup besar, artinya penyebaran data kemampuan berpikir kritis pada kelas eksperimen dan kelas kontrol relatif sama.

Pada hasil rataan skor posttest kemampuan berpikir kritis kelas eksperimen dan kelas kontrol terlihat perbedaan yang cukup besar, yaitu 17,00 pada kelas eksperimen 
dan 14,71 pada kelas kontrol. Jika skor rataan kemampuan berpikir kritis kedua kelas diubah ke persentase, maka persentase rataan skor pretest kemampuan berpikir kritis kelas eksperimen lebih kecil 0,9\% daripada kelas kontrol. Akan tetapi setelah diberi perlakuan atau treatment pada kelas eksperimen, maka persentase rataan skor posttest kemampuan berpikir kritis kelas eksperimen lebih besar 7,64\% daripada kelas kontrol. Persentase rataan diperoleh dari rumus $\frac{\text { skor rataan }}{\text { skor ideal }} \times 100 \%$

\section{Analisis skor pretest kemampuan berpikir kritis}

Analisis data skor pretest kemampuan berpikir kritis dalam penelitian ini menggunakan uji perbedaan rataan skor pretest kelas eksperimen dengan kelas kontrol. Tujuan uji perbedaan rataan skor pretest ini adalah untuk mengetahui kemampuan awal berpikir kritis siswa sebelum diberi perlakuan. Diharapkan hasil pretest kemampuan berpikir kritis siswa kelas eksperimen dan kelas kontrol hampir sama atau tidak terlalu berbeda secara signifikan agar kedua kelas ini dapat dijadikan sebagai sampel dalam penelitian ini. Sebelum data dianalisis, terlebih dahulu dilakukan uji prasyarat analisis yaitu uji normalitas dan uji homogenitas.

\section{a. Uji normalitas}

Uji normalitas data pretest kemampuan berpikir kritis dilakukan menggunakan uji statistik Sample Kolmogorov-Smirnov dengan taraf signifikansi 0,05. Uji normalitas dalam penelitian ini menggunakan hipotesis sebagai berikut:

$\mathrm{H}_{0}$ : sampel berasal dari populasi berdistribusi normal

$\mathrm{H}_{1}$ : sampel berasal dari populasi berdistribusi tidak normal

Kriteria pengujian yang dilakukan yaitu $\mathrm{H}_{0}$ ditolak, jika nilai Sig. ( $p$-value) $<\alpha$ (dimana $\alpha=0,05)$. Hasil rangkuman uji normalitas disajikan pada tabel sebagai berikut.

Tabel 2. Hasil Uji Normalitas Skor Pretest Kemampuan Berpikir Kritis

\begin{tabular}{ccccc}
\hline Hasil & Kelas & \multicolumn{2}{c}{ Kolmogorov-Smirnov } & Kesimpulan \\
& & $\mathbf{N}$ & Sig. & \\
\hline Pretest & Eksperimen & 25 & 0,200 & Terima $\mathrm{H}_{0}$ \\
& Kontrol & 24 & 0,143 & Terima $\mathrm{H}_{0}$ \\
\hline
\end{tabular}

Dari tabel di atas terlihat nilai signifikasi uji Kolmogorov-Smirnov skor pretest kemampuan berpikir kritis kelas eksperimen yaitu 0,200 lebih besar dari $\alpha=0,05$. Dengan demikian $\mathrm{H}_{0}$ diterima, artinya pada taraf signifikan 5\% data skor pretest kemampuan berpikir kritis kelas eksperimen berdistribusi normal. Begitu juga dengan nilai signifikasi uji Kolmogorov-Smirnov skor pretest kemampuan berpikir kritis kelas kontrol 
yaitu 0,143 lebih besar dari $\alpha=0,05$. Artinya pada taraf signifikan 5\% data skor pretest kemampuan berpikir kritis kelompok kontrol berdistribusi normal.

\section{b. Uji homogenitas}

Berdasarkan hasil uji normalitas data skor pretest kemampuan berpikir kritis siswa kelas eksperimen dan kelas kontrol yang berdistribusi normal, maka dilakukan uji homogenitas. Untuk menguji homogenitas maka digunakan uji Levene Statistic dengan taraf signifikansi 0,05 dengan menggunakan hipotesis sebagai berikut:

$$
\begin{aligned}
& \mathrm{H}_{0}: \sigma_{1}{ }^{2}=\sigma_{2}{ }^{2} \\
& \mathrm{H}_{1}: \sigma_{1}{ }^{2} \neq \sigma_{2}{ }^{2}
\end{aligned}
$$

Keterangan:

$\sigma_{1}=$ varians kelompok eksperimen

$\sigma_{2}=$ varians kelompok kontrol

Kriteria pengujian homogenitas yang digunakan yaitu jika nilai Sig. ( $p$-value $)<\alpha(\alpha$ $=0,05)$, maka $\mathrm{H}_{0}$ ditolak sedangkan untuk kondisi lain $\mathrm{H}_{0}$ diterima. Hasil rangkuman uji homogenitas disajikan pada tabel berikut.

Tabel 3 Hasil Uji Homogenitas Skor Pretest Kemampuan berpikir kritis

\begin{tabular}{cccccc}
\hline Hasil & Levene Statistic & $\boldsymbol{d f 1}$ & $\boldsymbol{d f 2}$ & Sig. & Keterangan \\
\hline Pretest & 0,811 & 1 & 47 & 0,372 & Terima $\mathrm{H}_{0}$
\end{tabular}

Berdasarkan tabel di atas, terlihat bahwa nilai sig. Untuk kedua kelas (kelas eksperimen dan kelas kontrol) lebih besar dari 0,05, yaitu 0,372. Sehingga $\mathrm{H}_{0}$ diterima, artinya varians populasi data pretest kemampuan berpikir kritis siswa kelas eksperimen dan siswa kelas kontrol homogen. Maka pengujian selanjutnya dilanjutkan dengan uji-t.

\section{c. Uji perbedaan rataan}

Berdasarkan hasil uji normalitas dan uji homogenitas data pretest kemampuan berpikir kritis kelas eksperimen dan kelas kontrol yang menyatakan bahwa data tersebut memenuhi uji prasyarat kenormalaan dan homogenitas. Maka dilanjutkan pada uji perbedaan rataan pretest dengan menggunakan independent sample t-test serta taraf signifikansi 0,05 dengan menggunakan hipotesis sebagai berikut:

$$
\begin{aligned}
& \mathrm{H}_{0}: \mu_{k e}=\mu_{k k} \\
& \mathrm{H}_{1}: \mu_{k e} \neq \mu_{k k}
\end{aligned}
$$


Keterangan:

$\mu_{k e}=$ rataan data pretest kemampuan berpikir kritis siswa yang belajar melalui pembelajaran multiliterasi (kelas eksperimen)

$\mu_{k k}=$ rataan data pretest kemampuan berpikir kritis yang belajar melalui metode pembelajaran ceramah (kelas kontrol)

Kriteria pengujian rataan data pretes kemampuan berpikir kritis yang digunakan yaitu jika nilai sig. ( $p$-value $)<\alpha(\alpha=0,05)$, maka $\mathrm{H}_{0}$ ditolak sedangkan untuk kondisi lain $\mathrm{H}_{0}$ diterima. Hasil rangkuman uji perbedaan rataan disajikan pada tabel berikut.

Tabel 4. Hasil Uji Perbedaan Rataan Skor Pretest Kemampuan Berpikir Kritis

\begin{tabular}{ccccc}
\hline \multicolumn{2}{c}{$\boldsymbol{t}$-test for } & Equality of Means & Kesimpulan & Keterangan \\
$\boldsymbol{t}$ & $\boldsymbol{d} \boldsymbol{f}$ & Sig. (2-tailed) & & \\
\hline$-0,269$ & 47 & 0,789 & Terima $\mathrm{H}_{0}$ & Tidak terdapat perbedaan \\
\hline
\end{tabular}

Berdasarkan uji t yang telah dilakukan, diperoleh nilai Sig. (2-tailed) $=0,789>0,05$. Kesimpulannya $\mathrm{H}_{0}$ diterima, yaitu tidak terdapat perbedaan yang signifikan antara data pretest kemampuan berpikir kritis siswa kelas eksperimen dan siswa kelas kontrol.

\section{Analisis skor posttest kemampuan berpikir kritis}

Analisis skor posttest kemampuan berpikir kritis dalam penelitian ini menggunakan uji perbedaan skor posttest yang bertujuan untuk mengetahui apakah ada perbedaan yang signifikan kemampuan akhir berpikir kritis antara siswa kelas eksperimen, yaitu siswa yang belajar dengan pembelajaran multiliterasi dengan siswa kelas kontrol yang belajar menggunakan metode pembelajaran ceramah.

Dari hasil signifikan itu akan dilihat apakah pembelajaran multiliterasi memberikan pengaruh pada kemampuan berpikir kritis siswa atau tidak. Sebelum data di analisis, terlebih dahulu dilakukan uji prasyarat analisis yaitu uji normalitas dan uji homogenitas.

\section{a. Uji normalitas}

Uji normalitas data posttest dilakukan menggunakan uji statistik One Sample Kolmogorov-Smirnov dengan taraf signifikansi 0,05 dengan menggunakan hipotesis sebagai berikut:

$\mathrm{H}_{0}$ : sampel berasal dari populasi berdistribusi normal.

$\mathrm{H}_{1}$ : sampel berasal dari populasi berdistribusi tidak normal 
Kriteria pengujian yang digunakan yaitu jika nilai Sig. ( $p$-value $)<\alpha(\alpha=0,05)$, maka $\mathrm{H}_{0}$ ditolak sedangkan untuk kondisi lain $\mathrm{H}_{0}$ diterima. Hasil rangkuman uji normalitas disajikan pada tabel di bawah ini.

Tabel 5. Hasil Uji Normalitas Skor Posttest Kemampuan Berpikir Kritis

\begin{tabular}{ccccc}
\hline Hasil & Kelas & \multicolumn{2}{c}{ Kolmogorov-Smirnov } & Kesimpulan \\
& & N & Sig. & \\
\hline \multirow{2}{*}{ Posttest } & Eksperimen & 25 & 0,85 & Terima $\mathrm{H}_{0}$ \\
& Kontrol & 24 & 0,81 & Terima $\mathrm{H}_{0}$
\end{tabular}

Dari tabel di atas terlihat bahwa nilai signifikasi uji Kolmogorov-Smirnov skor posttest kemampuan berpikir kritis kelas eksperimen adalah 0,85 dan kelas kontrol sama 081. Karena gig. ( $p$-value $) 0,2>\alpha(\alpha=0,05)$, maka $\mathrm{H}_{0}$ diterima. Artinya pada taraf signifikan $5 \%$ data skor posttest kemampuan beroikir kritis siswa kelas eksperimen dan kelas kontrol berdistribusi normal.

\section{b. Uji homogenitas}

Berdasarkan hasil uji normalitas data skor posttest kemampuan berpikir kritis siswa kelas eksperimen dan kelas kontrol yang berdistribusi normal, maka dilakukan uji homogenitas. Untuk menguji homogenitas maka digunakan uji Levene Statistic dengan taraf signifikansi 0,05 dengan menggunakan hipotesis sebagai berikut:

$$
\begin{array}{ll}
\mathrm{H}_{0} & : \sigma_{1}{ }^{2}=\sigma_{2}{ }^{2} \\
\mathrm{H}_{1} & : \sigma_{1}{ }^{2} \neq{\sigma_{2}}^{2}
\end{array}
$$

Keterangan:

$\sigma_{1}=$ varians kelompok eksperimen

$\sigma_{2}=$ varians kelompok kontrol

Kriteria pengujian homogenitas yang digunakan yaitu jika nilai Sig. ( $p$-value $)<\alpha(\alpha$ $=0,05)$, maka $\mathrm{H}_{0}$ ditolak. Sedangkan untuk kondisi lain $\mathrm{H}_{0}$ diterima. Hasil rangkuman uji homogenitas kemampuan berpikir kritis posttest disajikan pada tabel berikut.

Tabel 6. Hasil Uji Homogenitas Skor Posttest Kemampuan Berpikir Kritis

\begin{tabular}{cccccc}
\hline Hasil & Levene Statistic & $\boldsymbol{d f 1}$ & $\boldsymbol{d f 2}$ & Sig. & Keterangan \\
\hline Posttest & 1,059 & 1 & 47 & 0,309 & ${\text { Terima } \mathrm{H}_{0}}^{2}$
\end{tabular}

Berdasarkan tabel di atas, terlihat bahwa nilai sig. kemampuan berpikir kritis untuk kedua kelas (kelas eksperimen dan kelas kontrol) lebih besar dari 0,05, yaitu sebesar 0,309. Sehingga $\mathrm{H}_{0}$ diterima, artinya varians populasi data posttest kemampuan berpikir 
kritis siswa kelas eksperimen dan siswa kelas kontrol homogen. Maka untuk pengujian selanjutnya dilanjutkan dengan uji-t.

\section{c. Uji perbedaan rataan}

Berdasarkan hasil uji normalitas dan uji homogenitas data posttest kemampuan berpikir kritis kelas eksperimen dan kelas kontrol yang menyatakan bahwa data tersebut memenuhi uji prasyarat kenormalaan dan homogenitas. Maka dilanjutkan pada uji perbedaan rataan posttest kemampuan berpikir kritis dengan menggunakan independent sample t-test serta taraf signifikansi 0,05 . Uji perbedaan rataan skor posttest bertujuan untuk membuktikan HIPOTESIS PENELITIAN yaitu "Kemampuan berpikir kritis siswa kelas eskperimen yang belajar melalui pembelajaran multiliterasi lebih efektif daripada siswa kelas kontrol yang belajar melalui pembelajaran ceramah". Hipotesis yang diujikan adalah sebagai berikut:

$$
\begin{array}{ll}
\mathrm{H}_{0} & : \mu_{k e}=\mu_{k k} \\
\mathrm{H}_{1} & : \mu_{k e} \neq \mu_{k k}
\end{array}
$$

\section{Keterangan:}

$\mu_{k e} \quad=$ rataan data posttest kemampuan berpikir kritis siswa yang belajar melalui pembelajaran multiliterasi (kelas eksperimen)

$\mu_{k k}=$ rataan data posttest kemampuan berpikir kritis siswa yang belajar melalui metode pembelajaran ceramah (kelas kontrol)

Kriteria pengujian rataan data posttest kemampuan berpikir kritis yang digunakan yaitu jika nilai sig. ( $p$-value $)<\alpha(\alpha=0,05)$, maka $\mathrm{H}_{0}$ ditolak. Sedangkan untuk kondisi lain $\mathrm{H}_{0}$ diterima. Hasil perhitungan selengkapnya dapat dilihat pada lampiran, sedangkan hasil rangkuman uji perbedaan rataan skor posttest kemampuan berpikir kritis disajikan pada tabel berikut.

Tabel 7. Hasil Uji Perbedaan Rataan Skor Posttest Kemampuan Berpikir Kritis

\begin{tabular}{ccccc}
\hline \multicolumn{2}{c}{ t-test for Equality of Means } & Kesimpulan & Keterangan \\
\multirow{2}{*}{2,373} & $\boldsymbol{d f}$ & Sig. (2-tailed) & & \\
\hline & 47 & 0,022 & Tolak $\mathrm{H}_{0}$ & $\begin{array}{c}\text { Terdapat } \\
\text { perbedaan }\end{array}$ \\
\hline
\end{tabular}


Berdasarkan uji t yang telah dilakukan, diperoleh nilai Sig. (2-tailed) posttest kemampuan berpikir kritis sebesar 0, 022, dimana lebih kecil daripada $\alpha(\alpha=0,05)$. Maka kesimpulannya $\mathrm{H}_{0}$ ditolak, artinya terdapat perbedaan yang signifikan antara data rataan posttest kemampuan berpikir kritis siswa kelas eksperimen dengan siswa kelas kontrol, atau dengan kata lain kemampuan berpikir kritis siswa yang belajar melalui pembelajaran multiliterasi lebih efektif daripada siswa yang belajar melalui metode pembelajaran ceramah.

Pembelajaran multiliterasi memberikan efektivitas pada kemampuan berpikir kritis siswa karena mengoptimalkan pemahaman kognitif siswa dan media yang ada serta menempatkan keterampilan siswa dengan penguasaan media secara baik. Selama proses pembelajaran siswa diminta aktif mengeluarkan pendapat untuk mengoptimalkan kemampuan berbicara atau mengeluarkan pendapat siswa, serta siswa dibimbing untuk dapat mendayagunakan media dan sumber belajar yang ada. Hal ini didukung oleh pendapat Morocco (2008, hlm. 10) yang menyatakan bahwa keterampilan-keterampilan yang terkandung dalam pembelajaran multiliterasi adalah kemampuan membaca, kemampuan menulis, keterampilan berbicara, dan keterampilan penguasaan media informasi dan komunikasi.

Keempat keterampilan multiliterasi tersebut tidak dapat muncul jika tidak ada kerjasama antara siswa dengan guru, guru dengan siswa, serta siswa dengan siswa. Artinya dalam proses pembelajaran multiliterasi siswa harus dilibatkan secara langsung dalam proses pembelajaran. Proses pembelajaran IPA materi ekosistem dengan pembelajaran multiliterasi memerlukan profesionalisme guru secara total, artinya guru diminta untuk kerja secara total dalam proses pembelajaran dan mampu menciptakan ide kreatif agar minat dan bakat siswa muncul selama proses pembelajaran, serta siswa termotivasi dalam proses pembelajaran.

Guru juga harus mampu mengoperasikan teknologi agar siswa mampu mengembangkan keterampilan penguasaan media informasi dan komunikasi secara baik. Hal ini menuntut keseriusan guru dalam mengembangkan pembelajaran yang harmonis, bermutu, dan bermartabat sebagaimana tuntutan pembelajaran saat ini. Melalui model pembelajaran multiliterasi siswa. Hal ini sejalan dengan pendapat Moss (2010, hlm. 14) yang menyatakan bahwa pembelajaran multiliterasi menuntut tujuan agar guru selalu membantu siswa membaca dan mengaitkannya dengan berbagai teks ilmu lain lain dan menjadikan fungsi teks tersebut sebagai pesan untuk memperoleh informasi (adanya respon dari siswa dan guru dalam proses pembelajaran). 
Berdasarkan penelitian yang telah dilakukan siswa memperoleh informasi baru dan mengetahui bagaimana cara mereka berpikir secara kritis di dalam proses pembelajaran. Pembelajaran IPA materi ekosistem ini menampilkan beragam sumber belajar, pembelajaran di fokuskan kepada lingkungan dan membawa benda-benda yang berkaitan dengan pembelajaran sehingga siswa mudah memahami konsep dan materi. Hal ini memperkuat pernyataan Morocco (2008, hlm. 56) pembelajaran multiliterasi akan menyatukan bacaan dan sumber belajar untuk mendapatkan informasi bagi siswa, termasuk siswa SD. Pendekatan untuk mengajarkan siswa belajar dengan pembelajaran multiliterasi adalah ajarkan siswa untuk berani berbicara, ajarkan siswa untuk berpikir kritis, dan berikan siswa kesempatan untuk melakukan hal bermakna. Siswa SD akan sangat menyukai hal baru dan mereka dianggap dalam sebuah kelompok, itu akan menjadi poin penting bagi guru dalam meningkatkan kemampuan membaca siswa. Hal terpenting dalam pembelajaran multiliterasi adalah melaksanakan semua komponen model multiliterasi, yaitu (1) tujuan pembelajaran agar siswa tahu arah dan tujuan pembelajaran yang mereka lalui; (2) pertanyaan penting sebelum melakukan proses pembelajaran dengan tujuan sebagai panduan dalam proses pembelajaran serta meningkatkan motivasi siswa selama proses pembelajaran; (3) tahapan pembelajaran yang dapat diadaptasi dari tahapan yang diberikan para ahli, sesuai dengan kreativitas guru; (4) sumber belajar yang beragam, seperti pengetahuan awal siswa, buku, teks, gambar, video, perpustakaan, lingkungan yang ada pada sekitar siswa. Hal ini menghendaki ketersediaan bermacam sumber belajar yang mendukung terciptanya proses pembelajaran yang bermutu; (5) penilaian pembelajaran yang digunakan diharapkan adalah penilaian pembelajaran otentik; (6) komponen keluaran pada penelitian ini adalah kemampuan berpikir kritis dan kreatif siswa, serta kemampuan berkolaborasi dan berkomunikasi dengan baik pada guru, teman sejawat, dan masyarakat sekitar.

Hasil penelitian lain yang membahas tentang multiliterasi adalah penelitian Abidin (2014) dengan judul "perekayasaan pembelajaran literasi berbasis konsep multiliterasi, integratif, dan berdiferensiasi (MID) di Sekolah Dasar". Abidin menyimpulkan model pembelajaran literasi berbasis MID yang dihasilkan melalui penelitiannya adalah model pembelajaran literasi membaca yang berorientasi pada pengembangan proses dan hasil pembelajaran. Model pembelajaran literasi berbasis MID yang dikembangkan memiliki urgensi penting bagi peningkatan mutu proses dan hasil pembelajaran literasi membaca sehingga terbukti secara signifikan memiliki kontribusi bagi kebiasaan dan peningkatan kemampuan literasi membaca siswa. 
Selain itu penelitian Lestyarini (2013), dengan judul "model multiliterasi dalam perkuliahan pendidikan bahasa dan sastra Indonesia" juga membahas tentang pembelajaran multiliterasi. Lestyarini menyimpulkan model multiliterasi dapat dikembangkan pada berbagai kompetensi (linguistik, gestural, spasial), dimana dapat meningkatkan kebermaknaan pembelajaran bagi mahasiswa.

Pembelajaran multiliterasi juga bisa memadukan beberapa kajian bidang. Penelitian Concannon-Gibney dan McCarthy (2012) yang mencoba memadukan pembelajaran membaca dan sains. Penelitian ini menyimpulkan terdapat hubungan yang erat antara upaya guru mengembangkan kemampuan metakognisi siswa, proses inkuiri, strategi-strategi khususnya membaca, dan bagaimana siswa belajar. Penerapan strategi khusus membaca yang dipadukan dengan pembelajaran kolaborasi ternyata sangat efektif dalam meningkatkan kemampuan siswa dalam memahami wacana nonfiksi. Penerapan berbagai strategi membaca dalam konteks pembelajaran sains telah menunjukkan bahwa antara pembelajaran sains dan pembelajaran literasi bahasa memiliki keterhubungan yang jelas. Bertemali dengan kondisi ini model pembelajaran membaca pemahaman Do-Read-Do dipandang sebagai model pembelajaran membaca yang dapat diterapkan dalam konteks pembelajaran sains.

\section{SIMPULAN DAN SARAN}

Berdasarkan analisis dan pembahasan penelitian yang telah diuraikan sebelumnya, serta kajian teori dan metodologi penelitian ini maka dapat ditarik kesimpulan bahwa pembelajaran multiliterasi memberikan efektifitas terhadap kemampuan berpikir kritis siswa SD, terbukti bahwa rata-rata skor kemampuan berpikir kritis siswa yang belajar melalui pembelajaran multiliterasi adalah 17. Sedangkan rata-rata skor kemampuan berpikir kritis siswa yang belajar tidak menggunakan pembelajaran multiliterasi adalah 14,71. Maka dapat dimaknai bahwa pembelajaran multiliterasi memberikan efektifitas kepada siswa dalam meningkatkan kemampuan berpikir kritis. Siswa yang belajar dengan pembelajaran multiliterasi memberikan tanggapan positif terhadap model pembelajaran yang telah mempengaruhi kemampuan berpikir kritis dan berpikir kreatif mereka. Guru yang menggunakan model pembelajaran multiliterasi dalam proses pembelajaran juga memberikan respon positif. 


\section{DAFTAR PUSTAKA}

Abidin, Y, dkk. (2014). Perekayasaan pembelajaran literasi berbasis konsep multiliterasi, integratif, dan berdiferensiasi (mid) di sekolah dasar. [Laporan penelitian hibah bersaing]. Universitas Pendidikan Indonesia, Bandung.

Concannon, G.T. \& McCarthy, M.J. (2012) "The Explicit Teaching of Reading Comprehension in Science Class: a Pilot Professional Development Program”. Improving Schools. 15 (1). 73-88

Elaine, B.Johnson. (2011). Contextual Teaching \& Learning Menjadikan Kegiatan BelajarMengajar Mengasyikekan dan Bermakna. Bandung: kaifa.

Fauziah, Nurul Yuli,dkk. (2010). Kemampuan Guru SD dalam Mengembangkan Keterampilan Berpikir Kritis pada Pelajaran IPA. Jurnal Pena Ilmiah]. Vol 1 No.1 Universitas Pendidikan Indonesia.

Gibasa, Learning Sociaty. (2012). Membuat Anak Gemar dan Pintar IPA. Jakarta: Visi Media.

Lestyarini, B. (2013). Asesmen autentik dan relevansinya di era multiliterasi. [Online] http://staff.uny.ac.id/sites/default/files/makalah\%20ASESMEN\%20AUTEN TIK\%20DAN\%20RELEVANSINYA\%20DI\%20ERA\%20MULTILITERASI. pdf.

Maslichah, Asy'ari. (2006). Penerapan Pendekatan Sains Tekhnologi Masyarakat dalam Pembelajaran SAINS di Sekolah Dasar. Yogyakarta: Depdiknas.

McConachi, S.M., et al. (2010). Content matters: a disciplinary literacy approach to improving student learning. San Fransisco: Jossey-Bass A Wiley Imprint

Morocco, CC. (2008). Supported literacy for adolescents: transforming teaching and content learning for the twenty-first century. San Fransisco: Jossey-Bass A Wiley Imprint

Schummacher, S \& McMillan, J. H. (2001). Research in education a conceptual introduction (fifteen edition). New York \& London: Addison Wesley Longman, Inc 